\title{
Treating Policy Brokers Seriously: Evidence from the Climate Policy
}

\author{
Karin Ingold*, Frédéric Varone ${ }^{t}$ \\ ${ }^{*}$ University of Berne; ${ }^{\dagger}$ University of Geneva
}

\begin{abstract}
The advocacy coalition framework (ACF) pays special attention to "so-called" policy brokers when explaining policy change. However, this prominent policy approach neither clearly defines who the policy brokers are nor identifies under which institutional rules they have an influence on policy processes and outputs. This article thus formulates two theoretical hypotheses that complement the ACF and then proceeds to undertake the first empirical testing of these hypotheses within the Swiss climate policy (1990-2008). The empirical results show that, in the case under investigation, the strategic interest-based behavior of two policy brokers (i.e., one public administration and one political party), as well as two institutionalized veto points (i.e., optional referendum and parliamentary committee), are crucial factors explaining policy brokers' influence on policy process and change.
\end{abstract}

\section{INTRODUCTION}

The advocacy coalition framework (ACF) is a prominent approach used to investigate policy change and it pays special attention to so-called policy brokers. Following Sabatier and Jenkins-Smith (1993, see also Sabatier and Weible 2007, 192), the appropriate unit of analysis is a political subsystem composed of participants who regularly seek to influence policy within that subsystem, such as Swedish nuclear energy policy (Nohrstedt 2009b) or California Marine Protected Area Policy (Weible 2007) for example. A subsystem is composed of advocacy coalitions whose members can include legislators, agencies, and interest groups, as well as researchers and journalists; these all coordinate with one another based on shared beliefs. Policy brokers typically intervene in situations where two or more advocacy coalitions are in competition (e.g., pro- and contra-nuclear power coalitions [Nohrstedt 2009]; proand anti-MPA coalitions [Weible 2007]) about their beliefs and policy positions. The role of brokers is to then search for stability in the specific political subsystem and to mediate between the opponents in order to make compromise solutions feasible.

Although the ACF was developed in the American pluralist polity, a wider application in European countries and corporatist political systems can be observed over the last decade (see Sabatier and Weible 2007 and Weible et al. 2009 for an overview of empirical studies

The authors wish to thank the three anonymous reviewers and Craig Thomas for their careful reading of this article and their helpful suggestions. We are also grateful to Hanspeter Kriesi for his thoughtful comments. Address correspondence to the author at karin.ingold@ipw.unibe.ch. 
applying the ACF). As a consequence of these wider applications, the authors adapted some concepts to make the ACF better suited to different institutional contexts where consensual decision making is the rule (Sabatier and Weible 2007) or where political parties are also key players (Nohrstedt 2009; Weible 2007). Nevertheless, Weible, Sabatier, and McQueen (2009, 129, 132, and 134-5) explicitly recognized that most ACF applications largely overlook the role of policy brokers and institutional rules as important components of the ACF.

Concretely, there are still open questions, and ACF is lacking when it comes to explaining: (1) the mere existence of policy brokers (Who are policy brokers? What are their belief systems?); (2) their behavior during the policy-making processes (Do they have a strategic interest-based behavior to increase their power or are they oriented toward the search of stability within a policy subsystem?); and (3) their influence on policy outputs in different political systems (Under which institutional rules do policy brokers have an influence?).

The ACF revision that we propose here addresses these questions and intends to fill the significant gap by linking the following elements: the competition among advocacy coalitions within a subsystem, the role of policy brokers, and the institutional rules framing the decisionmaking process. This is very important when it comes to linking policy subsystems to general decision-making processes in a specific polity. Treating both policy brokers and institutional rules seriously thus allows us to better analyze the nexus between the actors configuration at the policy subsystem level on one hand and the general decision-making process which translates into collective choice outputs on the other. In that context, this contribution is perfectly congruent with the latest developments of the ACF undertaken by Nohrstedt and Weible (2010), Sabatier and Weible (2007), Weible (2007), and Nohrstedt (2009).

This article has two aims: first, to formulate theoretical hypotheses that complement the $\mathrm{ACF}$, and that - more generally speaking - take better into account the role and influence of policy brokers on policy change under specific institutional rules, and second, to proceed to a first empirical test of this extended framework by analyzing, in-depth, the brokerage activities and power games which have characterized the Swiss climate policy during the last two decades. ${ }^{1}$ The next sections are structured as follows. In the section "Policy Brokers within ACF: Two New Hypotheses," we introduce two additional hypotheses to the ACF in order to define brokers' role in policy processes. Section 3 presents the Swiss climate policy-making process as a case study, used to identify policy brokers and assess their influence on policy output. In section 4, we systematically test the two complementary hypotheses by combining two innovative methods: a quantitative Social Network Analysis (SNA) and a multi-criteria analysis (MA). Finally, we conclude by suggesting further paths of research, applying the $\mathrm{ACF}$ in various policy domains and countries.

\section{POLICY BROKERS WITHIN ACF: TWO NEW HYPOTHESES}

Various different theoretical frameworks dedicate special attention to the role of "policy brokers" or "policy entrepreneurs" when it comes to finding explanations for policy process and output, mainly in so-called cognitive approaches to policy analysis (Baumgartner

1 The data presented here were used for a PhD project (see Ingold 2010, 2008 in French). The aim of these earlier studies was a policy design and case study analysis of Swiss climate policy. The raw data were reanalyzed in this article to concentrate on a different aspect, namely the identification of brokers in a policy process. The authors consider an empirical illustration as important when expressing the central claim of this article, for example, a better definition of the role of policy brokers within the ACF. 
and Jones 1993; Jobert and Muller 1987; Kingdon 1995; Mintrom and Norman 2009; Mintrom and Vergari 1996; Sabatier and Jenkins-Smith 1993; Zachariadis 2007). However, these schools and approaches define policy brokers quite differently. Some scholars favor a more economic way of defining policy brokers, calling them entrepreneurs: policy entrepreneurs act on a politically profitable opportunity (Holcombe 2002, 143), have a competitive spirit (Schumpeter 1961), are primarily self-interested, manipulate their environment, and have leadership qualities (Arce 2001, 124). Other scholars are not so categorical and see entrepreneurs as usually creative actors who are nevertheless motivated by the pursuit of self-serving benefits (Kingdon 1995, 204). The multiple streams framework further states that policy entrepreneurs play a crucial role in capturing the attention of policy makers and manipulating it to their advantage (Zachariadis 2007,69). Other scholars are again closer to policy approaches but still highly prioritize the interest-driven characteristics of policy brokers (see, e.g., Schneider and Teske 1992, 742), their specific political skills such as personality, charisma, and an ability to manage people (Kuhnert 2001,21), and to take advantage of inefficiencies in public management (Christopoulos 2008).

All these definitions are different from the ACF concept, where policy brokers seek stability and play a crucial role in mediating conflicts between competing coalitions. In ACF terms, the output of a given decision-making process does not depend on an individuals' decision but on the interaction of actors' coalitions. The ACF views the policy process as a competition between coalitions of actors who advocate beliefs about policy problems and solutions. Actors are said to build advocacy coalitions independently of their organizational allegiances or institutional functions. The glue between members of a coalition is their shared belief systems (Sabatier and Weible 2007, 195). In the ACF, one distinguishes three levels of beliefs: the deep core beliefs, involving ontological assumptions; the policy core beliefs, these being normative beliefs that project an image of how the specific policy subsystem ought to be and provide the vision that guides a coalition's strategic behavior; and finally secondary aspects, which are preferences related to specific instruments and policy proposals in the specific subsystem (Sabatier and Weible 2007). If coalition members may defer in secondary preferences, they tend to agree on core (policy) beliefs (Sabatier and Jenkins-Smith 1993). The goal of each advocacy coalition is to successfully translate its beliefs into policy programs. Doing so, a coalition can find itself in conflict with other coalitions with different belief systems which are also trying to have an influence on the policy program. For such conflict situations, the ACF developed the concept of learning across coalitions. Policy-oriented learning is an important aspect of policy change (Weible 2007) and principally concerns the level of secondary aspects of the belief system (Sabatier 1988, 134).

In conflict situations, the tendency is for each coalition to ignore or misinterpret one another; and so-called policy brokers can be identified as a path to learning processes across coalitions. A policy broker's principal concern is to engage in reasonable compromise finding which will reduce intense conflict (Sabatier 1988, 155). Empirical evidence already exists about the pertinence of learning across coalitions in conflict situations (see, e.g., Sabatier and Jenkins-Smith 1993; Sabatier and Weible 2007), as well as about the proactive role of policy brokers (Elliott 2000; Ingold 2008; Jegen 2003). However, there is no explicit hypothesis within the ACF about the characteristics of policy brokers, their motivations to enter the policy game, and the institutional rules which shape their activities and success (see also Mintrom and Norman 2009, 657-8 and 661-2). 
In order to better grasp the concept of policy brokers within the ACF and in policy process theories in general, we suggest adding two new and complementary hypotheses. The first focuses on the belief system, self-interests, and strategic behavior of policy brokers within a policy subsystem, this being where we deduce our arguments from regarding the above outlined literature about brokers and entrepreneurs in policy processes. The second postulates that the influence of policy brokers depends on the institutionalized veto points constraining the general decision-making process within the political system.

\section{Interests and Strategic Behavior of Policy Brokers (Hypothesis 1)}

The original ACF has been criticized for not clearly defining policy brokers whose "dominant concerns are with keeping the level of political conflict within acceptable limits, and reaching some 'reasonable' solution to the problem" (Sabatier 1988, 141). Furthermore, the ACF does not explicitly consider the (material) self-interests of policy actors and of policy brokers beyond their belief systems. Several authors applying the ACF have, in fact, found that interests could also be a strong driving factor for policy actors to join an advocacy coalition (Kübler 2001; Nohrstedt 2009; Schlager 1995), Sabatier (Sabatier and Weible 2007, 197) himself admits that, under certain circumstances, interests may play a crucial role. In their own empirical study of offshore petroleum leasing, Jenkins-Smith and St Clair (1993) also conclude that interests can be crucial: they advance that for more material coalitions (typically motivated by economic purposes), self-interest can be a better indicator for coalition cooperation than core beliefs.

We question this subordination of interests to policy beliefs and argue here that such interest-based behavior best characterizes the policy brokers who do not have strong and cohesive belief systems (for the policy issue at stake) and, thereby, those who do not belong to one or another advocacy coalition. As argued by Mintrom and Norman $(2009,661)$, "some degree of self-interest must be at stake" in order to explain why policy brokers decide to allocate their scarce resources to brokerage activities without any certainty of their success. If the policy brokers were not motivated by self-interest and, at the same time, if they did not consider the policy as a fundamental issue for their own core beliefs, then it would be impossible to understand why they would invest time, expertise, personnel, etc., in the policy subsystem. The logical assumption which follows must, therefore, be that policy brokers are rational actors: they mobilize and act strategically (to find a compromise between advocacy coalitions) because their brokerage activities allow them to realize their own interests. Nonetheless, the content of these self-interests is dependent upon the type of policy brokers and could not be predefined. However, we expect two types of actors to be particularly motivated by self-interests rather than beliefs.

On one hand, this seems to be particularly true for political parties that are internally divided on the issue at stake and who may follow their strategic short-term interest in terms of internal party cohesion and voters' maximization. ${ }^{2}$ For example, Nohrstedt $(2009,12)$

2 In general, the ACF pays little attention to political parties in the subsystem; it does not specify how partisan rifts influence policy choice and the likelihood for policy change (Nohrstedt 2009, 17). This may be due to the US context of the ACF development, where political parties are obviously not key policy players. But if the ACF is to be applied to political systems where political parties are central actors, then it makes sense to consider them explicitly. Note that a similar suggestion was also made to enlarge the punctuated equilibrium model of Baumgartner and Jones - also characterized by an US bias - by integrating political parties in this theoretical approach of agenda setting (see in particular Walgrave and Varone 2008). 
convincingly demonstrates that the strategic interest related to vote maximization was a key explanation for the Swedish nuclear policy. In 1979, just before the 1980 elections, the Social Democrats launched a referendum on the phasing out of nuclear power, in order to avoid an internal party split on this issue and a conflict expansion during the electoral campaign and also, ultimately, to increase its chance of regaining power. Such behavior is also particularly plausible if a political party (playing a policy broker role) is located in the middle of the political (left-right) spectrum. It can play a pivotal role in building alternative winning coalitions, either with left or right parties belonging to competing advocacy coalitions.

On the other hand, similar reasoning also applies to public administrations. Administrative agencies when they do not have a specific mission or mandate in a subsystem, which would make them belong to a coalition - typically defend more neutral positions (according to the Weberian ideal-type of rational-legal bureaucracy) and do not have strong belief systems. Located between conflicting coalitions in the policy subsystem, they therefore have the opportunity to assume a mediating role which may increase their own political power and policy influence (through additional budget assignments, new implementation competencies, etc.). Elliott $(2000,89)$ demonstrates the brokerage role of the Natural Resource Management Project (NRMP) in Indonesian forest policy. Representatives of this project are found in offices belonging to the US Agency of International Development and to the US Ministry of Forestry. Elliott points out the ideal brokerage location of the NRMP as it included actors from both major coalitions in the subsystem.

The first new hypothesis (H1) thus reads as follows: "If policy actors have either no strong belief systems (on the specific policy issue at stake), are internally divided (on this issue), or defend more centrist positions than the advocacy coalitions in competition, they then use their belief independence to pursue their (material) self-interests and act strategically as policy brokers to seek stability between advocacy coalitions."

In order to test this hypothesis, we suggest the following three steps. (1) Policy brokers have first to be identified empirically as not taking part in or being placed at the border of one or another competing advocacy coalition, as they do not share their respective strong core beliefs. (2) The empirical analysis should then highlight the material self-interests of policy brokers which lead them to participate actively (despite the absence of strong core beliefs for the issue at stake) in the policy-making process. (3) Finally, there should be empirical evidence about the strategies implemented by policy brokers to engage in compromise finding between advocacy coalitions, while at the same time realizing their own interests.

\section{Institutionalized Veto Points, Devil Shift, and Policy Brokerage (Hypothesis 2)}

The ACF is also obviously marked by an underdevelopment when it comes to clarifying the complex interactions of subsystems (at the policy level), the institutional rules constraining the decision-making process (at the polity level), and the political actors with the formal authority to make binding decisions in all policy fields. ${ }^{3}$ Sabatier and Weible (2007) have in fact integrated some thoughts of comparative politics scholars in their latest ACF revision, in order to deal with less pluralist political systems than the American one. They consider,

3 Sabatier and Jenkins-Smith $(1993,17)$ adopt a decentralized concept of governance emphasizing problem-solving structures, rather than formal political authorities and their decisions. 
as variables influencing policy-making in a subsystem, both the openness of the political system and the degree of consensus needed for policy change. In short, the institutional rules inherent to a political system modify the "political opportunity structure" that each coalition may strategically exploit to promote - or even to impose - its beliefs and policy preferences. The authors do not, however, formulate an explicit hypothesis regarding the expected effects of political opportunity structures (which varies significantly between countries and among policy subsystems) on the behavior of advocacy coalitions and on the specific role of policy brokers. To fill this gap, we pay special attention to the impact of opportunity structures and concentrate on institutional rules, which are defined here as shared prescriptions that are mutually understood and predictably enforced in specific situations by agents responsible for monitoring conduct and imposing sanctions (Ostrom 2007, 23). As Ostrom (2005) presents in her typology, different institutional rules exist: they depend on the concerned tier of decision, such as constitutional collective choice, and operational decisions (Kiser and Ostrom 1982). We concentrate on the two first decision tiers and adopt a narrower definition of rules that shape the formal decision-making arrangement and define the participation of actors and their access to decision-making arenas. Such decision-making rules shape opportunity structures that affect, in ACF terms, the resources and behavior of advocacy coalitions. Institutionalized veto points constitute one such rule type and are of special interest as advocacy coalitions may activate them to conserve the status quo.

When developing this discussion further, and in line with the latest revision of the ACF, we argue that policy brokers are (more) influential in democracies characterized by several institutionalized veto points that can be activated by advocacy coalitions. We thus refer to the theory of veto players, as originally developed by Tsebelis $(1995,289,2002,2)$, which may be summarized as follows: the potential for policy change decreases with the number of veto players, the dissimilarity of their respective policy preferences (i.e., the lack of congruence between belief systems in the ACF) and their respective internal cohesion (i.e., the strength of advocacy coalitions in the ACF). Rephrased in ACF terms, this means that if very cohesive advocacy coalitions oppose each other, then policy change is very improbable as the dominant advocacy coalition will use institutionalized veto points to hinder any policy change.

Such a strategy is reinforced by the process of "devil shift" identified by Sabatier, Hunter, and McLaughlin (1987): an advocacy coalition generally tends to see the challenging advocacy coalition as being more powerful and more evil than it really is. As a corollary, it perceives itself as being less influential. This misperception, which is particularly common in high conflict situations, may lead to conflict escalation. Furthermore, and in line with the Tsebelis argument, this devil shift is contingent on the distance in belief systems of opponents (Weible et al. 2009, 132). In such situations, the use of veto points by the opposing advocacy coalition to block the decision-making process is (misperceived as) expected. This potential threat is problematic for advocacy coalitions, as "actors value losses more than gains" and "remembers defeats more than victories" (Sabatier and Weible 2007, 194). They will therefore eventually accept a negotiated agreement promoted by policy brokers, on the basis that otherwise their opponents may use veto points in an uncontrolled way.

The combination of both reasons (institutionalized veto points and devil shift) leads to the active search for a reasonable policy compromise and it is clear that policy brokers are well positioned to find such a compromise solution. By doing so, they prevent the use of 
veto points by one advocacy coalition to the detriment of another and thereby put an end to the conflict escalation. In this context, several authors have empirically identified or conceptually discussed the important role of brokers which help form compromises between competing advocacy coalitions that are often in a state of stalemate (Jegen 2003; Nagel 2006; Nohrstedt and Weible 2010).

One aim of this article is to take the link discussed in ACF literature (Sabatier et al. 1987; Weible et al. 2009) between the devil shift situation, the hurting stalemate, and policy brokers and to empirically test this link. The second hypothesis (H2) reads as follows: "If the political system offers several institutionalized veto points to advocacy coalitions engaging in the "devil shift," then policy brokers attempt to prevent advocacy coalitions from activating veto points and therefore have a great influence on the final policy output."

Robust testing of this second hypothesis includes four steps. (1) The identification of the institutionalized veto points that might be used by advocacy coalitions. (2) The empirical investigation should then demonstrate how the advocacy coalitions gradually engage in a "devil shift" through the threat of activating these veto points. (3) Furthermore, it has to be shown how policy brokers prevent this conflict expansion and the effective use of veto points. (4) Finally, the analysis should demonstrate that the policy actors belonging to the advocacy coalitions acknowledge the activities of policy brokers and value their mediating role within the subsystem. In other words, a counterfactual reasoning is required to ensure that the policy outputs would have been different without the intervention of the policy brokers.

In the next section, we present a case study on the Swiss climate policy, in order to test these two hypotheses which aim at extending the ACF.

\section{CASE STUDY: THE SWISS CLIMATE POLICY (1990-2008)}

Since the early 1990s, Switzerland was a strong partner in the elaboration and implementation process of the United Nations Framework on Climate Change Convention. In 2003, Switzerland signed the Kyoto Protocol, under which it committed to reduce $8 \%$ of its greenhouse gas emissions by 2012 compared to 1990 emissions. ${ }^{4}$ This decision clearly represented a "policy stalemate" (Sabatier and Weible 2007, 206) for the Swiss climate policy, insofar as all policy actors involved in the policy-making process viewed the continuation of the status quo as unacceptable. However, much earlier than this international commitment, the Swiss government had already planned a national climate mitigation strategy. In 1995, it launched the project of the $\mathrm{CO}_{2}$ law, which was introduced in 2000. The first implementation phase of the law relied on voluntary measures and, in case of the failure of this self-regulation, on a subsidiary $\mathrm{CO}_{2}$ tax. This initial step is an example of a successful public-private partnership between the Swiss Federal Administration and economic sectors. ${ }^{5}$ Nonetheless, the $10 \%$ emissions reduction goal of the law could not be reached by the nonmandatory instruments during this period. Thus, after 2002, a tax incentive on $\mathrm{CO}_{2}$ emissions should have been introduced. However, the political negotiation about this more constraining instrument strongly divided the political elite and led to an intense conflict expansion. The policy instruments adopted for the second phase in 2005 were $\mathrm{CO}_{2}$ tax on combustibles (implemented

\footnotetext{
$4 \mathrm{CO}_{2}$ contributes to more than $80 \%$ of Swiss greenhouse gas emissions. $\mathrm{CO}_{2}$ is emitted by three main sectors: transport, households, and industry; each one contributes almost by one-third to the overall emissions.

5 One example of such a public-private partnership is the target agreement for $\mathrm{CO}_{2}$ emissions reduction between the Swiss Agency for the Environment and the Swiss cement industry (http://www.detec.ch).
} 
in 2008) and a climate penny on motor fuels (implemented since 2005). This was not the expected solution and it marked a clear departure from the incentive $\mathrm{CO}_{2}$ tax (on both combustibles and motor fuels) that was initially defined as a subsidiary instrument in the $\mathrm{CO}_{2}$ law of 2000 .

In relation to the analysis of the two successive policy outputs reviewed above (voluntary agreements and subsidiary $\mathrm{CO}_{2}$ tax, and the $\mathrm{CO}_{2}$ tax on combustibles and climate penny on motor fuels), the following questions emerge: How can we explain the unpredictable policy change that happened in the Swiss $\mathrm{CO}_{2}$ law after the year 2000? Did policy brokers influence the policy output? If so, which institutional rules allowed them to mediate between the pro- and contra $\mathrm{CO}_{2}$-tax coalitions? We answer these questions and argue in the following paragraphs that the two additional hypotheses, as presented above, constitute an added value to understanding broker actions in the case of the Swiss climate policy.

\section{Data and Methodology: SNA, MA, and Content Analysis}

The data analyzed in this case study is based on 50 face-to-face interviews within 34 organizations and was collected during a PhD project between the years 2005 and 2006 (Ingold 2010, 2008). We also rely on a systematic content analysis of several official documents and, foremost on all opinions expressed by the policy actors during the pre-parliamentary consultation procedures (for a detailed presentation of this data, see Ingold 2008). In accordance with the ACF, we studied nearly two decades of Swiss climate policy and identified coalitions, power relations, and broker presence. To better understand policy change in the Swiss $\mathrm{CO}_{2}$ law, all empirical tests concerned the two outlined decision-making periods: the design and implementation of the first phase of the $\mathrm{CO}_{2}$ law between 1990 and 2000 and, then, the more recent developments between 2000 and 2008.

The first step was to identify members of the so-called "Swiss climate policy elite." We relied on the classical combination of positional, decisional, and reputational approaches for the definition of the elite. In line with Knoke et al. (1996, 7), formal organizations rather than individuals stand in the foreground of today's politics and form advocacy coalitions. This claim is of particular interest here because in the formal pre-parliamentary consultation phase, ${ }^{6}$ policy actors express their policy preferences that are then taken into account by political officials. ${ }^{7}$

\footnotetext{
6 As stated in the Federal Act on the Consultation Procedure (CPA, SR 172.061), such procedures are mandatory when drafting amendments to the Constitution or provisions of Federal Acts. As stated in the same Act, their specific purpose is of allowing cantons (national subunits), political parties, and interest groups to participate in shaping of opinion and decision-making process of the Confederation and to guarantee the feasibility of implementation and public acceptance. They take thus place before the decision making of Parliament and Government.

7 We are aware of the fact that individual survey respondents tend to replicate their personal belief systems, rather than that of their organization and that individuals are the ones who learn and act in a policy process. However, we controlled this by four empirical means: first, senior representatives of every organization were identified to ensure that individuals knowing the internal structure of the organization and experienced with the communication of its official viewpoint were involved in the survey. In most cases, executive members, such as directors and presidents, were therefore interviewed. Second, every interview question started with the sentence "in the viewpoint of your organization" to make clear that the individual evaluation was not of interest to us. Third, individual survey answers were then compared to the opinion expressed in official documents. Where necessary, the interview partner was solicited a second time to explain possible differences between their personal answers and the official statements. And fourth, where an aggregate actor showed an internal split of belief systems or a change in policy preferences over time, two or more representatives were interviewed. This is the reason, why for 34 organizations 50 interviews occurred.
} 
In accordance with the recommendation of Stokman (2004, 23), we apply a twodimensional approach concentrating on both structure and content. To empirically test the relational profile among actors and to investigate dominance, we applied SNA as a methodological adjunct to the theoretical tenets of the ACF. SNA provides an impressive toolbox for empirical analysis of social network structures and their relevance for opportunities and behavioral choices of actors. However, to take into consideration actors' belief systems, we have combined SNA with two more content-driven methodologies: the content analysis of the consultation procedures for both periods, as well as an MA for the second period. In order to reconstruct actors' policy preferences, this MA takes into consideration two different levels of beliefs: first, it weighs different criteria relevant in the specific subsystem (e.g., normative beliefs, such as the importance of ecological effectiveness or competitiveness of Swiss economy in the international market, thus relevant in the specific subsystem of Swiss climate policy). Second, actors involved in decision making also evaluate policy instruments (e.g., secondary aspects/instrumental assumptions that represent a translation of policy core beliefs). This methodological combination (SNA, MA, and content analysis) ${ }^{8}$ allowed us, in most cases, to test the concepts of the ACF twice, by applying SNA and MA/content analysis.

\section{Identification of Two Advocacy Coalitions}

Following traditional SNA (Wasserman and Faust 1994), two measures are important in order to identify coalitions in a conflict network: structural equivalence and density.

Participants to our survey were asked to indicate the convergence and divergence relations they shared with all other actors within the policy elite. With the gathered data, structurally equivalent actors could be identified: structural equivalence puts all actors having the same conflict profile into the same group. ${ }^{9}$ Actors of the same group are not necessarily linked by a relation, but they occupy the same position in the policy subsystem. This measure translates the ACF concepts in a pertinent manner as it structures a subsystem following actors' conflicting opinions about a specific policy field. In the two considered decades of $\mathrm{CO}_{2}$ law in Switzerland, three main groups can be identified: a first group, dominated by private sector representatives (pro-economy group); a second group, mainly constituted by science and Federal administration representatives (intermediate group); and a third group, dominated by left parties and green non-governmental organizations (NGOs) (pro-ecology group).

Groups of structurally equivalent actors are, however, not necessarily advocacy coalitions: following the ACF, members of a coalition must have a certain degree of internal coordination. Translated into SNA terms, convergence (and not divergence) relations should prevail among actors of the same coalition (Fischer 2003; Ingold 2008; Sciarini 1994). Density measures indicate if actors are linked through a majority of convergence relations (see table 1).

A positive density shows dominance of convergence relations compared to divergence relations. Density above 0.5 is considered as strong convergence and density above 0.25 as

8 Weible (2007, 113-4) recommended combining network data (to identify coalitions) with qualitative data gathered through documents, questionnaires, or interviews to identify beliefs, behavior, and strategies. In our case, MA operationalizes coalitions' belief systems. This datum was gathered through 50 interviews on questionnaire basis. 9 Structural equivalence was calculated using the software StOCNET: StOCNET 1.7 including BLOCKS 1.6,P2 4, PACNET, SIENA 2.4a, Ultras 1.2, and ZO 2.3 (6.0 Mb, February 8, 2006) developed by Stokman F., Snijders T., van Duijn M., ICS/University of Groningen, the Netherlands. 
Table 1

Densities from 1990 to 2000 and from 2000 to 2008

\begin{tabular}{|c|c|c|c|}
\hline & Pro-economy & Intermediate Group & Pro-ecology \\
\hline \multicolumn{4}{|l|}{$1990-2000$} \\
\hline Pro-economy & .236 & -.051 & -.164 \\
\hline Intermediate group & -.046 & .039 & .10 \\
\hline Pro-ecology & -.309 & .333 & .65 \\
\hline \multicolumn{4}{|l|}{$2000-08$} \\
\hline Pro-economy & .355 & -.32 & -.101 \\
\hline Intermediate group & -.143 & .011 & .56 \\
\hline Pro-ecology & -.606 & .111 & .292 \\
\hline \multicolumn{4}{|c|}{$\begin{array}{l}\text { Note: The density and centrality measures were calculated using the software UCINET: UCINET } 6 \text { for Windows developed by Borgatti, } \\
\text { Everett, and Freeman (Analytic Technologies, Harvard). This datum was presented earlier (see Ingold 2010, in French) in a case study } \\
\text { presentation about instrument design in Swiss climate policy. Compared to that earlier work, the data serve here as a first test of the } \\
\text { additional hypotheses suggested by the authors. The aim of this contribution is thus to show how policy brokers can be conceptualized } \\
\text { under the ACF and, furthermore, be empirically identified. The empirical test is of particular interest here as the authors are not making } \\
\text { a simple theoretical claim. }\end{array}$} \\
\hline
\end{tabular}

medium (Sciarini 1994). Within-group densities are outlined in the diagonals of table 1; they are of interest here to see if members of the same group share most notable convergence relations and can thus be identified as coalitions.

The pro-economy group and the pro-ecology group show, for both study periods, a medium to strong positive density among their members ( $0.236 / 0.355$ for the pro-economy group; 0.65 / 0.292 for the pro-ecology group). The intermediate group, however, is not a coalition in our subsystem: divergence relations invalidate convergence relations.

Following these first results of the network analysis, we have two main coalitions during both analyzed periods of the $\mathrm{CO}_{2}$ law. The very stable and homogenous pro-economy coalition contained 11 representatives from Swiss industry, transport, and right parties. This coalition furthermore counted among its members, the inventors of the climate penny, the Swiss Petrol Union, and the Touring Club. The pro-ecology coalition grew in numbers between the first and the second phase and, from 2000 contained, the Federal Office for the Environment (FOEN), representatives from left parties and green NGOs. The intermediate group could not be identified as an advocacy coalition per se. Between the two analyzed periods, it lost four members to the pro-ecology coalition and in the second phase included 14 members mainly representing the Federal Administration ${ }^{10}$ and scientific institutions. The Christian Democratic People's Party (PDC), a center-right party often defending a political compromise, was also member of this intermediate group.

The following section of our study reconstructs coalitions looking at actors' beliefs and policy preferences (Brecher et al. 2010); it should strengthen the results found in applying SNA. ${ }^{11}$ For the first period between 1990 and 2000, a content analysis of the official policy positions held by the various policy actors was conducted to identify coalitions' preferences about policy instruments. We principally looked at the actors' statements during the preparliamentary phase and, specifically, at the statements made during the 1996 consultation procedure where the first project of the $\mathrm{CO}_{2}$ law was discussed (Federal Council 1997). For the

10 All Federal agencies participating in the Swiss climate elite (except the FOEN which is member of the pro-ecology coalition) belonged to this intermediate group.

11 See also Ingold (2011) for a detailed discussion about ally/opponent networks in relation with belief consistency among coalition members. 
second period between 2000 and 2008, we applied an MA to identify actors' policy core and secondary aspects. ${ }^{12} \mathrm{MA}$ is used to undertake a comparative assessment of alternative measures, in our case policy instruments. The key output is a ranking of instrument preferences of every actor and coalition. ${ }^{13}$

Four criteria were defined as policy core indicators: environmental effectiveness, economic effectiveness, equity, and competitiveness. In turn, the four policy instruments, all possible options for the second phase of the $\mathrm{CO}_{2}$ law, were defined as secondary aspects: voluntary agreements, $\mathrm{CO}_{2}$ tax, climate penny, and tradable permits. After weighting all four criteria, the participants to the survey gave marks to the four instruments, while still taking into account the four evaluation criteria. ${ }^{14}$ Coherence in policy core and secondary aspects was assessed by investigating whether a dominant preference structure among coalition members could be identified (see hereafter).

The two coalitions which had already been identified by applying SNA made coherent choices in core and secondary beliefs (table 2): following official statements of the 11 members in the pro-economy coalition, all of them preferred, first and foremost, voluntary agreements in the first phase of the $\mathrm{CO}_{2}$ law (Federal Council 1997; Lehmann and Rieder 2002). ${ }^{15}$ In the second phase, the pro-economy coalition preferred the climate penny: this policy instrument was ranked first and the tax was ranked as last by all 11 members participating in the survey. ${ }^{16}$ These 11 justified their choice with the criteria of economic effectiveness and/or competitiveness in the market. ${ }^{17}$ Since 1990, the pro-ecology coalition preferred the $\mathrm{CO}_{2}$ tax (Federal Council 1997). This was confirmed for the second phase by the MA analysis where all members of the pro-ecology coalition ranked the tax first $(5$ members of the pro-ecology coalition ranked the tax as preferred option together with other policy instruments; the climate penny was however always ranked last). They justified this choice in the second phase by using the criteria of environmental effectiveness. ${ }^{18}$ Again, the intermediate group did not fulfill coalition's characteristics: its members provided a very heterogeneous assessment of evaluation criteria, ${ }^{19}$ which meant that they had weak coherence about their policy core. Coherence in policy core beliefs is a crucial condition for the identification of a coalition in ACF terms (Sabatier and Jenkins-Smith 1993). On the level of secondary aspects of the belief system, almost all actors of the intermediate group preferred, among other

12 The survey took place in fall 2005. Actors' policy preferences were thus investigated via the MA for the second phase. As it is problematic to ask survey participants about their past policy preferences (interviewees tend to replicate current preferences in the past), preferences for the first phase were investigated via a content analysis of the opinions expressed by all policy actors during the consultation procedure. This documentary analysis was also duplicated for the second phase of the law.

13 Concretely, we applied Electre II, which calculates an index of concordance and an index of discordance. This enables us to evaluate each pair of instruments evaluated by every survey participant and weighted by each evaluation criterion. For a detailed outline of the method and the underlying mathematical algorithm, see Ingold $(2008,210)$ and Schärlig (1985).

14 Every instrument received a mark from 1 to 6 for its performance to fulfill a specific criterion. Specifically, every instrument received four marks, one for each performance criteria.

15 They approved the law only because of the subsidiary characteristic of the $\mathrm{CO}_{2}$ tax.

16 Apart from one actor, who mentioned having equal preference for all policy instruments.

17 Two actors evaluated the economic effectiveness, one actor the competitiveness, and seven actors both criteria as the most important for Swiss climate policy. Only one actor mentioned preferring the environmental effectiveness.

18 Eight actors evaluated the environmental effectiveness as the only and most important criterion. One actor mentioned all criteria being important.

19 The 14 actors of the intermediate group combine the four evaluation criteria in 8 different ways. No preferred criterion can thus be identified. 
Table 2

Coalitions and Beliefs in Two Periods (1990-2000; 2000-08)

\begin{tabular}{|c|c|c|c|}
\hline & $\begin{array}{l}\text { Pro-economy } \\
\text { Coalition }\end{array}$ & $\begin{array}{c}\text { Intermediate } \\
\text { Group } \\
\text { (not a coalition) }\end{array}$ & $\begin{array}{l}\text { Pro-ecology } \\
\text { Coalition }\end{array}$ \\
\hline \multicolumn{4}{|l|}{$1990-2000$} \\
\hline Number of actors & 11 actors & 18 actors & 5 actors \\
\hline Type of actors & 9: Industry, transport & 5: Federal agencies & 1: Federal agency \\
\hline & 2: Right parties & $\begin{array}{l}\text { 6: Science } \\
\text { 1: Center-right party } \\
\text { 1: Trade union } \\
\text { 5: Green NGOs }\end{array}$ & $\begin{array}{l}\text { 1: Trade union } \\
\text { 1: Green NGOs } \\
\text { 2: Green and } \\
\text { left parties }\end{array}$ \\
\hline $\begin{array}{l}\text { Policy preferences } \\
\text { on secondary aspects } \\
\text { (policy instruments) }\end{array}$ & $\begin{array}{l}\text { Voluntary } \\
\text { agreements of } \\
\text { the private } \\
\text { sector }\end{array}$ & $\mathrm{CO}_{2} \operatorname{tax}$ & $\mathrm{CO}_{2} \operatorname{tax}$ \\
\hline \multicolumn{4}{|l|}{$2000-08$} \\
\hline Number of actors & 11 actors & 14 actors & 9 actors \\
\hline Type of actors & $\begin{array}{l}\text { 8: Industry, transport } \\
\text { 2: Right parties } \\
\text { 1: Private consultant firm }\end{array}$ & $\begin{array}{l}\text { 5: Federal agencies } \\
\text { 3: Science } \\
\text { 1: Center-right party } \\
\text { 2: Trade unions } \\
\text { 2: Green NGOs } \\
\text { 1: Industry }\end{array}$ & $\begin{array}{l}\text { 1: Federal agency } \\
\text { 2: Science } \\
\text { 4: Green NGOs } \\
\text { 2:Green and } \\
\quad \text { left parties }\end{array}$ \\
\hline $\begin{array}{l}\text { Policy preferences } \\
\text { on secondary aspects } \\
\text { (policy instruments) }\end{array}$ & Climate penny & $\begin{array}{l}\mathrm{CO}_{2} \text { tax } \\
\text { (among other instruments) }\end{array}$ & $\mathrm{CO}_{2} \operatorname{tax}$ \\
\hline
\end{tabular}

Note: A detailed list of all organizations that participated in our survey and were members of the Swiss climate elite can be found in Appendix. Again, MA results were gathered in the above-mentioned PhD project. For more details about policy instrument design and preferences, see Ingold (2010) and (2008, in French).

instruments, the $\mathrm{CO}_{2}$ tax. ${ }^{20}$ This phenomenon can be explained in relation to the similar position all these actors held in the network (same structural equivalence).

On the basis of SNA, documentary content, and MA analysis of actors' opinions, we conclude that we had two competing advocacy coalitions (pro-economy and pro-ecology) during the considered decade of $\mathrm{CO}_{2}$ law in Switzerland. ${ }^{21}$ The output used today is made up of the $\mathrm{CO}_{2}$ tax on combustibles and the climate penny on motor fuels, each instrument having been preferred by one main coalition but rejected by the other. No coalition was dominant enough to impose its policy preferences as the unique solution in Swiss climate policy. Furthermore, the international pressure of the Kyoto Protocol, where Switzerland committed by its ratification to reduce $8 \%$ of its $\mathrm{CO}_{2}$ emissions, was not perceived as an external factor for policy change. First, we observe a change in secondary aspects; external factors under the ACF are, however, of higher relevance in core belief change. And second, the choice of the climate penny, evaluated as an instrument with weak ecological effectiveness and thus unable to reach the

20 In the first phase between 1990 and 2000, they already preferred this instrument. And as a result of the MA, 13 out of 14 mention to prefer the tax among the other three instruments.

21 Our empirical results confirmed the conclusion of previous research on the Swiss energy policy elite (see in particular Varone and Aebischer 2001, Kriesi and Jegen 2000, 2001). 
emissions' reduction goal (see Thalmann and Baranzini 2006), is further proof of the weak influence of international pressure on national policy design in the analyzed case. Finally, if international climate policy and the Swiss commitment in the Kyoto Protocol had had a large impact on national policy making, actors greatly involved in international decision making, such as the FOEN, the Environment Department (DETEC), or several other scientific institutions, would most probably have been empowered in the subsystem. However, these actors did not all hold a dominant position in the network and again the international arena did not play a key role in the definition of the policy compromise.

As coalition dominance and international pressure do not explain policy change in secondary aspects of Swiss climate policy, in the following section, we investigate the role of policy brokers in the facilitation of finding a compromise between the two competing coalitions.

\section{Identification of Two (Potential) Policy Brokers}

The conflict between the pro-economy and the pro-ecology coalitions was shown by two main indicators. First, both coalitions competed about core beliefs and policy preferences and, second, they shared significant conflict relations with one other as indicated in table $1 .^{22}$ In such cases, the ACF focuses on to the concept of learning across coalitions and the presence of so-called policy brokers: brokers mediate between the coalitions in order to find stability and to bring a feasible policy compromise to its success (Sabatier 1988, 133s). By testing if brokers were present in the $\mathrm{CO}_{2}$ law decision-making process, one may thus answer the question about how today's output of penny and tax was built and decided upon.

SNA and MA are again combined to identify policy brokers in the Swiss climate policy subsystem. A prominent SNA concept used to identify gatekeepers within a network is betweenness centrality: betweenness centrality was developed by Freeman (1979) and shows how many times an actor is located between two other actors. ${ }^{23}$ A high betweenness centrality means that an actor controls information flow in the policy network and thereby obtains a strategic and powerful position. In additional to this, reputational power was also deduced from the survey: every participant was asked to indicate the most important actors in Swiss climate policy during the two study periods.

Following the ACF's broker concept, and translated to network terms, only actors linking members from both coalitions are able to obtain a mediating position in the subsystem. Moreover, in order to mediate between different conflicting beliefs and to search stability in the subsystem (Sabatier and Jenkins-Smith 1993), policy brokers should defend more centrist beliefs and hold a more moderate position. These assertions are operationalized by again looking at our MA results and focusing on actors with moderate belief systems.

Whether actors of all kind belong or do not belong to advocacy coalitions, ${ }^{24}$ the consensus style of policy making in Switzerland encourages administrative agencies to play the

22 In the period $2000-08$, for example, the density of the conflict relations between the pro-economy and the proecology members is of -0.1 and from pro-ecology to pro-economy of -0.6 . (see table 1 )

23 The corresponding question asked during the survey was: "With which actors did your organization collaborate closely during the elaboration (1990-2000) and the recent implementation (2000-2008) of the Swiss $\mathrm{CO}_{2}$ law?"

24 'The distinction between 'advocate' and 'broker', however, rests on a continuum. Many brokers will have some policy bent, whereas advocates may show some serious concern with system maintenance. The framework merely insists that policy brokering is an empirical matter that may or may not correlate with institutional affiliation: Although high civil servants may be brokers, they are also often policy advocates - particularly when their agency has a clearly defined mission" Sabatier (1993, 27). 
Table 3

Reputational Power and Centrality of Actors Belonging to the Intermediate Group

\begin{tabular}{|c|c|c|c|c|}
\hline \multirow[t]{2}{*}{ Actors } & \multicolumn{2}{|c|}{$1990-2000$} & \multicolumn{2}{|c|}{$2000-08$} \\
\hline & $\begin{array}{c}\text { Reputational Power, } \\
\text { Maximum, } 32=100 \% \\
(\%)\end{array}$ & $\begin{array}{l}\text { nBetweeness } \\
\text { Centrality }\end{array}$ & $\begin{array}{c}\text { Reputational Power } \\
\text { Maximum, } 35=100 \% \\
(\%)\end{array}$ & $\begin{array}{c}\text { nBetweeness } \\
\text { Centrality }\end{array}$ \\
\hline SFOE & 66 & 1.1 & 83 & 6.1 \\
\hline PDC & 53 & 0 & 72 & 13.7 \\
\hline AenEC & 6 & 0 & 74 & 1.1 \\
\hline DETEC & 22 & 0 & 72 & 1 \\
\hline SECO & 38 & 4.1 & 23 & 1.5 \\
\hline FFA & 25 & 0.5 & 14 & 0.1 \\
\hline OEBU & 16 & 1.8 & 23 & 1.5 \\
\hline USS & 6 & 0 & 3 & 0 \\
\hline Equiterre & 13 & 0 & 6 & 0.3 \\
\hline Infras & 31 & 0 & 43 & 0.3 \\
\hline Prognos & 31 & 0 & 49 & 0 \\
\hline NCCR & 0 & 0 & 0 & 0 \\
\hline
\end{tabular}

Note: Reputational power: the higher the number, the more important an actor is viewed as by all other actors of the network. Betweenness centrality: the higher the number, the more central an actor is, linking members of the network that would not be related to each other without him. "nbetweenness" indicates the normalized betweenness centrality in $\% ; 100 \%$ corresponds to the maximum possible betweenness centrality in the whole network. In the 1990-2000 collaboration network, the maximum betweenness was $17.5 \%$ obtained by the FOEN. The mean is $1.8 \%$, all actors located above have a considerable betweenness centrality. The highest betweenness in the 2000-08 collaboration network was obtained by the WWF (29.4\%), but the collaboration relations mentioned by this green NGO were rarely confirmed by the other actors in the network, so this result must be analyzed with prudence. The mean is $6 \%$.

role of policy brokers (Sabatier and Jenkins-Smith 1993, 215). Moreover, researchers and scientific staff are also typically able to absorb (or even bring in) technical information (Sabatier and Weible 2007, 192): these actors are therefore predisposed to holding more neutral positions in a subsystem. This is why we concentrate here on the intermediate group, which is dominated by the two types of actors of interest: public administration and science. Members belonging to the intermediate group are in a better position to be identified as policy brokers: as actors outside a competing coalition, they would be in a profitable position to mediate. But, as their betweenness centrality indicates (see numbers in table 3 below), they are poorly integrated and related to few others. They are, therefore, not predisposed to being policy brokers.

The Swiss Federal Office of Energy (SFOE) is an exception; SFOE could be identified as a potential policy broker, having a high reputational power and a high betweenness centrality and linking all actors in the network, including members of both competing coalitions. SFOE was a very strong partner of the Swiss government when it came to choosing the policy output of the $\mathrm{CO}_{2}$ law. When the government saw the dilemma between the two polarized coalitions and their difference concerning the policy instruments, the SFOE proposed to present a mix of tax on combustibles and climate penny on motor fuels. ${ }^{25}$ Furthermore, the SFOE abandoned its own preferences (tax and tradable permits) in order to find a political compromise and could therefore be viewed as a real policy broker in the Swiss Climate policy.

25 This situation resembles what Mintrom and Norman $(2009,653)$ describe in their recent work about policy entrepreneurship and policy change as follows: "Risk aversion among decision makers presents a major challenge for actors seeking to promote significant policy change." 
The second actor identified as a policy broker candidate was the PDC. The role of the PDC was a priori not as active as the SFOE's. Nonetheless, in the pre-parliamentary decisionmaking phase, it was already one of the only actors which chose the solution of a mix between the preferred instrument of the pro-ecology coalition $\left(\mathrm{CO}_{2} \mathrm{tax}\right)$ and the preferred instrument of the pro-economy coalition (climate penny). These findings were confirmed during the interviews with two PDC representatives, where they insisted that their contacts with members from the two main advocacy coalitions were intense and important (Ingold 2008). Furthermore, PDC, as a governmental party, had a significant influence on the decisions of the Federal Council, and the government itself was more comfortable with its final choice of a mix between two instruments with the support of one of its member's parties. ${ }^{26}$

To summarize the results of the SNA, the MA and the documentary content analysis, we may conclude that we have identified two potential policy brokers (SFOE and PDC) who were involved in the search for stability in the second phase of the Swiss $\mathrm{CO}_{2}$ law and helped, as stated by the ACF, to find a feasible policy compromise.

\section{TEST OF THE TWO EXTENDED ACF HYPOTHESES}

Nonetheless, it is still necessary that we clearly demonstrate how these two actors actually acted as policy brokers and thereby test our two research hypotheses (see the procedure of testing presented in sub-sections 2.1. and 2.2.).

\section{SFOE and the PDC as Strategic Policy Brokers}

Regarding Hypothesis 1, our empirical data have shown that neither the SFOE nor the PDC belonged to either of the two competing advocacy coalitions (pro-economy versus pro-ecology) and neither had strong beliefs in favor of one or the other policy instrument under discussion. During the interview with a directorate member of SFOE, it became clear that SFOE actually preferred an overall $\mathrm{CO}_{2}$ tax in combination with tradable permits (see also MA results). But as the directorate member pointed out: "At some point, our Agency became aware that a pragmatic solution was needed. The opponents to the tax did mobilize all resources to promote the climate penny. In order to prevent a deadlock in the process and to come up with a feasible solution, our office made the suggestion to the Federal Council to consider the combination of a tax on combustibles and a penny on motor fuels." 27

In a similar vein, the PDC supported the instrument mix from the early stage of the preparliamentary phase. Its motivation, however, was a different one: the PDC was internally split: some of its members preferred the $\mathrm{CO}_{2}$ tax and the others supported the climate penny. This division was confirmed during our interviews, where one of the party members

26 The Swiss government (Federal Council) is constituted by seven members from four parties: two Social Democrats (PSS), two Free Democrats (PLR), two representatives of the Swiss People's Party (UDC), and one Christian Democrat (PDC). The seats in the National Council (lower Chamber of the Parliament) are divided among the most important political parties as follows: Left: Social Democratic Party of Switzerland (PSS, 19.5\% of votes; 43 seats) and Green Party of Switzerland (GPS, 9.6\% of votes; 20 seats); Center: PDC (14.5\% of the votes ; 31 seats); Right: Free Democratic Party and Liberal Party (PLR, $15.8 \%$ of votes; 31 seats) and Swiss People's Party (UDC, $28.9 \%$ of votes; 62 seats). This division shows the pivotal role the PDC may play between left and right parties. Its votes are necessary to create winning coalitions both on the left (PSS and Green Party) or on the right side (PLR and UDC) of the partisan spectrum.

27 Interview with a directorate member of SFOE, the November 20, 2005, in Bern, Switzerland. 
mentioned preferring the tax, whereas another indicated a preference for the penny. ${ }^{28}$ Finally, the PDC did not opt for a majoritarian vote among its members but rather preferred to support the combined policy mix, as was confirmed by the president and PDC representative of the Parliament Committee for the Environment. ${ }^{29}$ This representative also pointed out that during the parliamentary discussion - it became clear that the climate penny had far more chances to pass the decision-making process than the tax. An instrument mix seemed thus the best solution why the PDC made a Parliamentary intervention, suggesting the gradual introduction of the tax. ${ }^{30}$ These statements show that it was not especially difficult for the federal agency or for the center-right party to abandon parts of their own policy preferences to play the role of mediator.

Furthermore, we can also identify the self-interests of these two policy brokers in order to explain why they decided to invest resources in brokerage activities. The FOEN is the leading agency in Swiss climate policy. It was responsible for the $\mathrm{CO}_{2}$ bill formulation, for officially representing Switzerland in the international Kyoto negotiations and, also, was foreseen as the implementer of the subsidiary $\mathrm{CO}_{2}$ tax and the related tradable permits. The SFOE was therefore a rather peripheral actor within the Federal administration, even if this agency was co-responsible for monitoring the voluntary measures implemented by private actors during the first phase of the law. In the second phase, the SFOE's interest was to gain more power, new implementing competencies, and more resources as the budget of SFOE's main Program to promote energy efficiency and renewable energies (called EnergySwiss) was cut by $40 \%$ at the start of the second phase of the $\mathrm{CO}_{2}$ law. ${ }^{31}$ Directly related to this, the SFOE had an interest in promoting the climate penny, which was planned to be implemented by a private foundation. The SFOE has a long tradition of collaboration with private actors, principally those related to the implementation of the EnergySwiss Program. In this regard, one of SFOE's most important partners is the Energy Agency representing the Swiss private sector. As the directorate member of SFOE mentioned in our interviews, the SFOE saw the climate penny as a possible means of strengthening the collaboration with the Energy Agency and also its own Energy Efficiency Program. ${ }^{32}$ Therefore, it clearly promoted an instrument mix which strengthened its own policy position. The PDC was also motivated by self-interest, namely vote maximization. The PDC did not have very clear beliefs in the $\mathrm{CO}_{2}$ case but had an interest in putting a political decision forward in order to gain power as a pivotal party in Swiss parliament and government. This point was again addressed in the interviews: the PDC representative made clear that it was expected that he, as president of the Parliamentary committee, would suggest a solution which represented the opinion of the majority of committee members. His goal was thus to achieve vote maximization within both the committee and Parliament, by supporting a combined solution of tax and penny.

Finally, we can also observe the concrete power strategy that both policy brokers put in place. The SFOE used two strategies to push forward its compromise solution and to directly influence the policy output. First, during the internal consultation of public

28 Interviews with two parliamentarians of the PDC, on the November 11 and the December 6, 2005, respectively, were held in Bern, Switzerland.

29 Interviews with a parliamentary representative of the PDC, on the December 6, 2005, in Bern, Switzerland.

30 The PDC suggested linking the amount of the tax to the inflation. The Parliament finally decided on a gradual introduction, but not in relation to inflation, but in relation to the achieved $\mathrm{CO}_{2}$ reductions. The 1 ess $\mathrm{CO}_{2}$ that is reduced, the higher the tax price.

31 SFOE: http://www.bfe.ch.

32 Interview with a directorate member of SFOE, the November 20, 2005, in Bern, Switzerland. 
administration units (i.e., mandatory internal consultation of all Federal agencies which are concerned by a bill project), it suggested that the tax and penny should be presented to the actors of the formal consultation procedure (i.e., mandatory external consultation of all stakeholders outside the public administration) not only separately but also in combination. Second, during an informal meeting with the Swiss government, the SFOE suggested choosing the policy mix of tax on combustibles and penny on motor fuel, despite poor support for this policy solution during the formal external consultation procedure (Ingold 2008). The SFOE thus acted to smooth the progression in a nonvisible (internal consultation and informal meeting with Federal Council), but very influential manner. We can therefore conclude that the SFOE was sufficiently institutionally implicated, informed, and consulted during the pre-parliamentary phase to pass its message to the Swiss government. Nonetheless, it also managed to maintain a sufficient distance from advocates of both competing coalitions, in order that it might control the process from a somewhat neutral position.

The strategy of the PDC relies on influencing the decision of the Federal Council. As a governmental party, it could not only influence actors during the pre-parliamentary phase but even participate in the final decision of the Federal Council. It is true that influence can take place in the whole network, but decision making is reserved for those with the authority to make binding decisions. The second strategy of the PDC was to influence the final decision through different venues in Parliament. First, and as was mentioned above, the leader of the Parliamentary committee responsible for the $\mathrm{CO}_{2}$ law was a PDC representative and thus had the opportunity to directly integrate the idea of an instrument mix into the message of the committee to the overall Parliament (see also discussion of hypothesis 2). ${ }^{33}$ Second, during Parliament's plenary sessions, the PDC was the only actor that openly supported the mix between tax and penny. Different PDC representatives therefore took the opportunity to encourage this compromise when deadlock was reached among the parties of the left and parties of the right - supporting an overall $\mathrm{CO}_{2}$ tax and penny on motor fuels, respectively. ${ }^{34}$

In sum, all three steps could be verified and hypothesis 1 is thus corroborated for the case of Swiss climate policy: the two brokers SFOE and PDC did not take part in either of the two coalitions; both had a self-interest in promoting a policy compromise, and both finally pursued a strategy to directly influence the final decision.

\section{Optional Referendum and Parliamentary Committee as Institutionalized Veto Points}

We now turn to the testing of hypothesis 2 regarding the expected high impact of policy brokers in political systems with a high number of institutionalized veto points and a "devil shift" process between advocacy coalitions. To that end, we first identify the main institutionalized veto points that could be used by advocacy coalitions. Switzerland represents an emblematic case of consensus democracy (Lijphart 1999; Neidhart 1970). Specifically, policy actors opposing a policy change may use direct-democratic instruments to challenge the dominant advocacy coalition. A small minority of voters or parliamentarians may overturn policy decisions made by the parliamentary majority through an optional referendum. Uncertainty for the dominant advocacy coalition is thus introduced to the policy-making

\footnotetext{
33 The opinion of the responsible committee is important as in these committees all parliamentary parties are represented. As the committee members count as experts on the specific question, the overall Parliament tends to follow the committee's opinion or, at the very least takes it into consideration for the final vote (see more details below). 34 Official parliamentary statements are found under http://www.parlament.ch.
} 
process through the strategic use of direct democracy (Vatter 2009). The threat of launching an optional referendum, and thus blocking any changes to the (policy) status quo, acts like a Damocles sword threatening the whole decision-making process (Papadopoulos 2001); as a consequence, it leads to power-sharing institutions and large governmental coalitions (Neidhart 1970).

Further, the policy considerations of all policy actors (e.g., political parties, interest groups, trade unions, environmental associations, etc.), which might otherwise make use of the optional referendum after the parliamentary phase, are already integrated at the pre-parliamentary phase of the legislative process - where the initial policy proposal is elaborated - in order to avoid an ex post referendum with an uncertain outcome. In a nutshell, we consider the optional referendum as a key institutionalized veto point that might be used by competing advocacy coalitions. Tsebelis $(2002,125)$ labeled this situation as a "veto player referendum" as the decision to hold a referendum belongs to one of the veto players (i.e., one of the competing advocacy coalition in the ACF). We must also highlight another veto point used during the parliamentary stage of the law-making process (Tsebelis 2002, 99-105). Before entering the plenary agenda of the Federal Assembly, a legislative proposal is first discussed within a specialized parliamentary committee. In Switzerland, there are 12 permanent committees ( since 1992), each responsible for one policy field. Seats within each committee are distributed according to the strength of parliamentary groups (i.e., the number of MPs representing political parties in Parliament), and the committee's debates are generally organized by mutual agreement between parties. A committee is free to rewrite governmental proposals and has control over its own timetable. Parliamentary committees de facto have strong (definition) power as the Federal Assembly eventually adopts some $95 \%$ of the committee proposals sent to the plenum (Lüthi 2007, 128). Thus, MPs who belong to one or another advocacy coalition, whereas simultaneously being a member of a committee, may strategically use this arena to politicize the policy issue and to block, at least for some time, the decision-making process.

This outline of possible veto points in Swiss decision-making processes shows on the one side that our case study constitutes an ideal case in which to test the second hypothesis presented here; but on the other side, it also points out the limitations of this research in generalizing to cases where institutionalized veto points are not as easily identifiable or present at all.

The second element of interest used to test the second hypothesis is the existence of a "devil shift" situation in the Swiss climate policy case. We have three sources of information to investigate devil shift: First, SNA results; second, the policy preference ranking provided by MA; and third, an in-depth analysis of parliamentary and interview statements. Table 1 again shows the increase in conflictive relations (negative density scores) between the two main coalitions during the second phase of the $\mathrm{CO}_{2}$ law. This phenomenon is accompanied by a significant increase in convergence relations between the members of the pro-economy coalition. Second, the ranking of coalitions' preferred instruments showed that no member of the pro-economy coalition would prefer the tax and no member of the pro-ecology coalition, the climate penny. There were, therefore, clearly adverse interpretations made by the coalitions of one another's policy preferences and beliefs.

Third, by analyzing the statements of the different parties in parliamentary plenary sessions, it is clear that the negotiations between the right and the left reached a deadlock situation. No party considered the (partial) adoption of another coalition's preferred measure. In these discussions, 
one also notices that supporters of the climate penny were less aggressive and alarmed than tax supporters. The reason for this is that the decision of the government to introduce a tax would only be the first step. In a second step, the Parliament then has to decide about the tax price. As stated several times during the interviews, Parliament members knew that they could block the whole process by simply maintaining a refusal to accept the (revised) tax price suggested by the government. Both brokers, but principally the PDC - divided between the two coalitions - knew of the extent of the conflict and the "devil shift" between both coalitions, and could strategically actaccordingly.

In the above outlined analysis, it was clear that if the Federal government introduced the tax on motor fuels (instead of the climate penny), the risk would have been very high that representatives of the pro-economy coalition would have blocked its introduction in the parliamentary phase during the tax price negotiations. To avoid the use of veto points during the parliamentary phase, the two policy brokers acted early and engaged in an active search for a policy compromise in the pre-parliamentary phase. As outlined above, the SFOE contributed by suggesting the integration of the instrument mix to the government prior to the government launching the formal consultation procedure. The PDC on its side took the opportunity to support this instrument mix from a very early stage in this consultation.

Finally, it was clear that several actors in the subsystem recognized the brokerage potential of PDC and SFOE. Although the six parliamentary representatives from the left (PSS and Green Party) and the right (PRL and UDC) would have preferred that their supported instrument (and no compromise solution, as suggested by the PDC) passed the decision-making process, during the interviews, they all recognized the important role that the PDC played in the consensual policy solution finding (see also its reputational power, table 3 ).

The brokerage role of SFOE was recognized in an even more explicitmanner: apart from five members of the two main coalitions including the FOEN, ${ }^{35}$ the SFOE recognized its brokerage role by considering a mix of penny and tax in both the pre-parliamentary phase and in the final governmental decision as a "strategic and pragmatic act of mediation." ${ }^{36}$ Moreover, the head of the Ministry of Environment, Transport, Energy, and Communication (DETEC) and government member confirmed in a letter to the authors that the evening before he made public the decision of the combined tax and penny introduction, he had invited the Director of FOEN and two private sector representatives from the Petrol Union and the Swiss Business Federation (economiesuisse) to his office in Bern. His aim was to investigate "how these important actors would accept the mixed solution between tax and penny." Furthermore, the Minister also mentioned that SFOE, although not the leading agency in $\mathrm{CO}_{2}$ issues, was also invited and that its presence was "crucial as it was originally SFOE's suggestion to combine these instruments." "37 The vice-president of SFOE further confirmed the participation in this informal meeting and highlighted his role as mediator knowing of "both situations, the one of the FOEN and the DETEC, wanting the introduction of the tax as written in the law, and the one of the penny inventors, wanting to avoid a tax on motor fuels.",38

In sum, we identified that both advocacy coalitions had the opportunity to address institutionalized veto points and that they were engaged in "devil shift" and that both

35 Author's results from interviews with FOEN, economiesuisse, Swissmem, scientific expert, and AEnEc conducted in fall/winter 2005 .

36 Interview with a directorate member of SFOE, the November 20, 2005, in Bern, Switzerland.

37 Letter from the Minister to the authors from December 2, 2005.

38 Interview with a directorate member of SFOE, the November 20, 2005, in Bern, Switzerland. 
policy brokers engaged in conflict prevention, which was also recognized by several actors in the subsystem. On the basis of these empirical elements, we conclude that hypothesis 2 was confirmed within the Swiss climate policy system.

\section{Added Value of the ACF to Analyze Policy Brokerage}

The testing of both of the hypotheses has demonstrated the added value of an ACF approach in comparison to other approaches, such as those suggested by interest-based theories. First, the ACF concentrates on the functional role of policy brokers in a subsystem, namely their ability to negotiate and compromise between competing coalitions. Their position in a policy process thus goes beyond the realization of personal self-interests. This point is clearly confirmed in our case study where the two policy brokers' behavior and actions were characterized not only by pure self-interests but other varying factors.

Second, interest-based policy theories (pluralism, rational choice, etc.) tend to focus only on a restricted number of self-interested, sometimes even opportunistic stakeholders. The $\mathrm{ACF}$, however, takes into account all actors constituting part of the subsystem, concentrating foremost on their belief systems. Again, this point is crucial if one wants to identify brokers and analyze compromise finding: policy brokers tend to have a larger network horizon (including different actors from the two or more competing coalitions and not only those motivated and active through personal interests) than, for example, purely strategic and self-interested policy entrepreneurs.

Finally, and this argument found a fundamental split in the pro-economy coalition within Swiss climate policy: the industry, as combustible consumer, had completely different interests than the transport representatives and petrol importers - typically motor fuel consumers. An interest-based approach would have argued that the first would not support the climate penny, but rather be against a combustible tax and in favour of a motor fuels tax. Only the in-depth analysis of these actors' belief systems, as suggested by the ACF, could finally identify the fact that all these actors formed part of the same coalition, despite the fact that they were differently affected by the different policy instruments of the $\mathrm{CO}_{2}$ law.

\section{CONCLUSION}

This article focused on the role of policy brokers in mediating between advocacy coalitions in a policy subsystem; this being an area neither theoretically discussed nor empirically tested enough under the ACF. For this reason we added two hypotheses to concretize the broker position and role in a political conflict: both hypotheses directly addressed former critics to the ACF, which stated that this framework underestimates actors' interests and strategic behavior compared to beliefs; and that it does not pay enough attention to institutional rules (i.e., veto points) under which policy brokers successfully influence policy change. Conceptual and empirical insights presented in this article have however implications beyond the $\mathrm{ACF}$ literature and constitute an added value for future research on the role and identification of brokers in policy process analysis.

Taking the example of Swiss climate policy, we provided an insight into how two brokers acted according to their institutional positions (as public administration and governmental political party), and helped to avoid one or the other coalition from using either veto points in Parliament or the optional referendum, in order to block the policy decision and lead to issue expansion and conflict escalation. Brokers' strategic behavior, knowledge of the situation 
(i.e., "devil shift" between advocacy coalitions) and self-interests also had an impact on the extent of their influence in the final output design. These conclusions clearly support recent empirical analysis aimed at the improvement of the ACF hypotheses and methodology (Nohrstedt 2009; Weible 2007). These conclusions are furthermore entirely compatible with previous studies that used the ACF to analyze policy change in Switzerland. ${ }^{39}$

We therefore conclude that our analysis constitutes a strong starting point, which can be used to consider both ACF theory revision and methodological challenges to confirm or falsify our research results. There is moreover a need to have analytical categories such as veto points to provide a general perspective on the impacts of institutional rules on advocacy coalitions and policy brokers strategies. ${ }^{40}$ Several authors had previously suggested combining the literature on policy entrepreneurship, the ACF and other approaches on policy change (e.g., incrementalism, policy streams, institutionalism, punctuated equilibrium, epistemic communities or policy design; see Mintrom and Norman 2009; James and Jorgensen 2009; Meijerink 2005). However, these authors did not explicitly consider the veto players' theory as a good means of complementing the ACF and explaining under which institutional rules policy brokers are successful. This is not particularly surprising as the veto players theory mainly focuses on policy stability. Nonetheless, we suggest that a serious consideration of institutionalized veto points (e.g., multi-party government, federalism, courts decisions) is a crucial explanatory factor which explains the influence of policy outputs, particularly in case of "devil shift" and conflict escalation. Of course, it is still an open question as to how policy brokers are likely to act in a political system which does not offer several institutionalized veto points. We might assume that policy brokers would have little influence on the policy output in such a case.

Our study also tackled a methodological challenge by introducing formal SNA for ACF hypotheses testing. Of course, SNA cannot replace a careful analysis of actors' belief systems. In order to understand the source of conflict and to identify the coalition structure in the subsystem, documentary content analysis and MA was necessary in our empirical study. Other techniques are also available that can be used to identify core and secondary values of belief systems (e.g., discourse analysis, survey, interviews; see therefore also Brecher et al. 2010; 2009; Sabatier and Jenkins-Smith 1993; Sabatier and Weible 2007). However, our main argument is that a combination of both SNA and another technique ensures a more robust identification of both advocacy coalitions and policy brokers. ${ }^{41}$ It is moreover important to couple the (mainly structural and static) analysis of an advocacy coalition at the subsystem level, with a "process tracing" approach of the whole decision-making process. This triangulation of methods allows for the simultaneous consideration of the relative impacts on policy outputs of belief systems, material (self-) interests and institutional variables (such as veto points).

Finally, it seems evident that the two hypotheses that we proposed should be tested in different policy subsystems and in various national contexts, in order that their general validity may be evaluated. The two independent variables might be necessary but not

39 For example, Kübler's ACF application to Swiss drug policy (2001) also points to the fact that institutional rules (i.e., direct democracy) are important when it comes to explaining major and minor policy changes (Kübler 2001). The author demonstrates how a popular initiative "Youth without drugs" ("Jugend ohne Drogen") constituted a threat for the "harm reduction advocacy coalition" which then engaged a learning process in order to stay in power. This was a typical situation of what Sabatier and Jenkins-Smith (1993) call learning within coalitions.

40 This point seems even more relevant for studies comparing different countries and/or policy domains.

41 In that way, brokers can be defined as a structural group (such as members of an advocacy coalition). Their specificity is that they neither structurally (relational profile; structural equivalence) nor ideologically (belief system) belong to any advocacy coalition. 
sufficient conditions for the impact of brokers on policy change. We thus suggest three further research steps to build upon our limited case study.

First, the Swiss Climate policy is a "success story" of both policy brokerage and policy change. It would be very beneficial to expand the empirical basis by also considering negative cases. In other words, it would be valuable to conduct systematic comparisons of empirical cases characterized by both an active role of policy brokers and either policy change or policy stability. Explaining both change and stability (despite intense policy brokerage) within an integrated theoretical framework is still a major challenge (Mintrom and Vergari 1996).

Second, we should better isolate the "net impacts" of policy brokers on policy processes and outputs. In particular, we have to test empirically if the individual qualities of successful policy brokers (as proposed for example by Mintrom and Norman 2009; Goldfinch and Hart 2003, but also Beach 2004 or Tallberg 2004 in the field of EU politics) represent a necessary and sufficient condition for engineering policy change. For the ACF in particular, this applies to systematically comparing policy brokers activities (in a "devil shift" situation) with other conditions affecting the likelihood of policy change through cross-coalition learning (such as a hurting stalemate, a high technicality and tractability of the issue at stake, the existence of a professional forum, etc.). The framework for studying collective learning in collaborative arrangements developed by Gerlak and Heikkila (2011) could be a promising approach to better isolate the specific impact of policy brokers from the influence of additional variables impacting both, learning processes (i.e., change of some element in coalitionś beliefs system), and learning outputs (i.e., change in policy instruments). These authors argue that boundaryspanning actors who are connected to multiple members of a policy domain represent a crucial factor fostering collective learning processes (Gerlak and Heikkila 2011, 18).

Third, and in line with the recommendation of Mintrom and Norman (2009, 661-2), we argue that cross-national and cross-sector studies of policy brokering are urgently required. The numerous case studies published so far suffer from conceptual and methodological problems concerning the impacts of specific institutional rules on policy brokers' influence. If institutional factors do matter (as also postulated in the extended version of the ACF; see Weible 2007, 114), then the challenge is to better link policy games at the subsystem level with politics and institutional rules framing the general decision-making process (see also Nohrstedt and Weible 2010). The conventional classification of countries according to their institutional features (e.g., Lijphart 1999) is of little value in explaining the final substantive content of public policies. Varone et al. (2006) have, for example, compared the policies regulating biomedical technologies adopted in nine European countries, Canada and the USA. Thisstudy clearly demonstrated that there is no convergence in the content of the policies adopted by consensual versus majoritarian countries, or in federalist versus unitary state structures, etc. To draw valid inferences about the nature of policy process and outputs in different political systems, we suggest always combining actor-based conditions (i.e., belief system of advocacy coalitions and interest of brokers) with institutional rulesbased conditions (i.e., veto points). Future empirical studies might thus apply the following research designs: the comparison of two policy sectors (different actors configuration) in the same country (similar veto points); or the comparison of the same policy domain (similar actors configuration) in different countries (different veto points). 
Appendix 1

Members of the Swiss Climate Elite Interviewed during the $\mathrm{CO}_{2}$ Law Survey

\begin{tabular}{|c|c|c|c|c|}
\hline \multirow[b]{2}{*}{ Abbreviation } & \multirow{2}{*}{$\begin{array}{l}\text { Organizations } \\
\text { Full Name }\end{array}$} & \multirow[b]{2}{*}{ Type } & \multicolumn{2}{|c|}{$\begin{array}{l}\text { Coalition } \\
\text { Membership }\end{array}$} \\
\hline & & & $1990-2000$ & $2000-08$ \\
\hline Economiesuisse & $\begin{array}{l}\text { Swiss Business } \\
\text { Federation }\end{array}$ & $\begin{array}{l}\text { Umbrella organization } \\
\text { representing the Swiss } \\
\text { economy supported } \\
\text { by more than } 30,000 \\
\text { businesses of all sizes, } \\
\text { employing a total of } \\
1.5 \text { million people } \\
\text { in Switzerland }\end{array}$ & Pro-economy & Pro-economy \\
\hline UP & Swiss Petrol Union & $\begin{array}{l}\text { Representing } \\
95 \% \text { of the Swiss } \\
\text { petrol industry } \\
(27 \text { members in } 2009)\end{array}$ & Pro-economy & Pro-economy \\
\hline Swissmem & $\begin{array}{l}\text { The Swiss Mechanical } \\
\text { and Electrical } \\
\text { Engineering } \\
\text { Industries }\end{array}$ & $\begin{array}{l}\text { Umbrella organization } \\
\text { of Swiss mechanical, } \\
\text { electrical and } \\
\text { engineering industries } \\
\text { (MEM industries) }\end{array}$ & Pro-economy & Pro-economy \\
\hline Cemsuisse & $\begin{array}{l}\text { Association of the } \\
\text { Swiss Cement } \\
\text { Industry }\end{array}$ & $\begin{array}{l}\text { Umbrella organization of } \\
\text { Swiss cement producers }\end{array}$ & Pro-economy & Pro-economy \\
\hline $\mathrm{HEV}$ & $\begin{array}{l}\text { Swiss House Owners } \\
\text { association }\end{array}$ & & Pro-economy & Pro-economy \\
\hline TCS & $\begin{array}{l}\text { Touring Club } \\
\text { Switzerland }\end{array}$ & $\begin{array}{l}\text { More than } 1,5 \text { million } \\
\text { members; the } \\
\text { organization with } \\
\text { most private members } \\
\text { in Switzerland }\end{array}$ & Pro-economy & Pro-economy \\
\hline FRS & $\begin{array}{l}\text { Road traffic } \\
\text { association }\end{array}$ & $\begin{array}{l}\text { Umbrella organization } \\
\text { of car importers and } \\
\text { private traffic in } \\
\text { Switzerland }\end{array}$ & Pro-economy & Pro-economy \\
\hline Energieforum & & $\begin{array}{l}\text { Representing industry } \\
\text { and private concerns in } \\
\text { energy } \\
\text { consumption issues }\end{array}$ & Pro-economy & Pro-economy \\
\hline UDC & Swiss People's Party & $\begin{array}{l}\text { Two seats in the } \\
\text { Federal Council } \\
\text { (government); } 28.9 \% \text { of } \\
\text { the votes and } 62 \text { seats in } \\
\text { the National Council } \\
\text { (lower chamber) }\end{array}$ & Pro-economy & Pro-economy \\
\hline PLR & Free Democratic Party & $\begin{array}{l}\text { Two seats in the } \\
\text { Federal Council } \\
\text { (government); } 15.8 \% \\
\text { of the votes and } 31 \text { seats } \\
\text { in the National Council } \\
\text { (lower chamber) }\end{array}$ & Pro-economy & Pro-economy \\
\hline
\end{tabular}


Appendix 1 (continued)

Members of the Swiss Climate Elite Interviewed during the $\mathrm{CO}_{2}$ Law Survey

\begin{tabular}{|c|c|c|c|c|}
\hline \multirow[b]{2}{*}{ Abbreviation } & \multirow{2}{*}{$\begin{array}{c}\text { Organizations } \\
\text { Full Name }\end{array}$} & \multirow[b]{2}{*}{ Type } & \multicolumn{2}{|c|}{$\begin{array}{l}\text { Coalition } \\
\text { Membership }\end{array}$} \\
\hline & & & 1990-2000 & $2000-08$ \\
\hline Factor AG & & Private consultancy firm & $\begin{array}{l}\text { Intermediate } \\
\text { group }\end{array}$ & Pro-economy \\
\hline SGCI & $\begin{array}{l}\text { Swiss Association } \\
\text { of Chemical and } \\
\text { Pharmaceutical } \\
\text { Industry }\end{array}$ & $\begin{array}{l}\text { Umbrella organization } \\
\text { of chemical and } \\
\text { pharmaceutical } \\
\text { enterprises and } \\
\text { laboratories }\end{array}$ & Pro-economy & $\begin{array}{l}\text { Intermediate } \\
\text { group }\end{array}$ \\
\hline AEnEc & $\begin{array}{l}\text { Energy Agency } \\
\text { for the Economy }\end{array}$ & $\begin{array}{l}\text { Representing the } \\
\text { Swiss economy } \\
\text { and industry in } \\
\text { energy concerns }\end{array}$ & $\begin{array}{l}\text { Intermediate } \\
\text { group }\end{array}$ & $\begin{array}{l}\text { Intermediate } \\
\text { group }\end{array}$ \\
\hline PDC & $\begin{array}{l}\text { Christian Democratic } \\
\text { People's Party }\end{array}$ & $\begin{array}{l}\text { One seat in the } \\
\text { Federal Council } \\
\text { (government); } \\
14.5 \% \text { of the votes } \\
\text { and } 31 \text { seats in the } \\
\text { National Council } \\
\text { (lower chamber) }\end{array}$ & $\begin{array}{l}\text { Intermediate } \\
\text { group }\end{array}$ & $\begin{array}{l}\text { Intermediate } \\
\text { group }\end{array}$ \\
\hline Infras & & $\begin{array}{l}\text { Private scientific } \\
\text { institution }\end{array}$ & & \\
\hline Prognos & & $\begin{array}{l}\text { Private scientific } \\
\text { institution }\end{array}$ & $\begin{array}{l}\text { Intermediate } \\
\text { group }\end{array}$ & $\begin{array}{l}\text { Intermediate } \\
\text { group }\end{array}$ \\
\hline NCCR Climate & $\begin{array}{l}\text { National Competence } \\
\text { Center of research } \\
\text { about climate change }\end{array}$ & $\begin{array}{l}\text { Scientific institution } \\
\text { of the Swiss } \\
\text { national science } \\
\text { foundation }\end{array}$ & $\begin{array}{l}\text { Intermediate } \\
\text { group }\end{array}$ & $\begin{array}{l}\text { Intermediate } \\
\text { group }\end{array}$ \\
\hline Equiterre & & Green NGO & $\begin{array}{l}\text { Intermediate } \\
\text { group }\end{array}$ & $\begin{array}{l}\text { Intermediate } \\
\text { group }\end{array}$ \\
\hline OEBU & $\begin{array}{l}\text { Association for ecological } \\
\text { integration in business } \\
\text { management }\end{array}$ & $\begin{array}{l}\text { Representing } \\
\text { ecological } \\
\text { and sustainable } \\
\text { concerns within } \\
\text { Swiss private } \\
\text { sector }\end{array}$ & $\begin{array}{l}\text { Intermediate } \\
\text { group }\end{array}$ & $\begin{array}{l}\text { Intermediate } \\
\text { group }\end{array}$ \\
\hline USS & $\begin{array}{l}\text { Swiss Federation of } \\
\text { Trade Unions }\end{array}$ & Trade Union & $\begin{array}{l}\text { Intermediate } \\
\text { group }\end{array}$ & $\begin{array}{l}\text { Intermediate } \\
\text { group }\end{array}$ \\
\hline SFOE & $\begin{array}{l}\text { Swiss Federal } \\
\text { Office of Energy }\end{array}$ & Federal Agency & $\begin{array}{l}\text { Intermediate } \\
\text { group }\end{array}$ & $\begin{array}{l}\text { Intermediate } \\
\text { group }\end{array}$ \\
\hline SECO & $\begin{array}{l}\text { State Secretariat for } \\
\text { Economic Affaires }\end{array}$ & Federal Agency & $\begin{array}{l}\text { Intermediate } \\
\text { group }\end{array}$ & $\begin{array}{l}\text { Intermediate } \\
\text { group }\end{array}$ \\
\hline DETEC & $\begin{array}{l}\text { Federal Department } \\
\text { of the Environment, } \\
\text { Transport, Energy, } \\
\text { and Communication }\end{array}$ & Federal Department & $\begin{array}{l}\text { Intermediate } \\
\text { group }\end{array}$ & $\begin{array}{l}\text { Intermediate } \\
\text { group }\end{array}$ \\
\hline FFA & $\begin{array}{l}\text { Federal Finance } \\
\text { Administration }\end{array}$ & Federal Agency & $\begin{array}{l}\text { Intermediate } \\
\text { group }\end{array}$ & $\begin{array}{l}\text { Intermediate } \\
\text { group }\end{array}$ \\
\hline
\end{tabular}


Appendix 1 (continued)

Members of the Swiss Climate Elite Interviewed during the $\mathrm{CO}_{2}$ Law Survey

\begin{tabular}{|c|c|c|c|c|}
\hline \multirow[b]{2}{*}{ Abbreviation } & \multirow{2}{*}{$\begin{array}{l}\text { Organizations } \\
\text { Full Name }\end{array}$} & \multirow[b]{2}{*}{ Type } & \multicolumn{2}{|c|}{$\begin{array}{l}\text { Coalition } \\
\text { Membership }\end{array}$} \\
\hline & & & 1990-2000 & $2000-08$ \\
\hline Proclim & $\begin{array}{l}\text { Forum for Global } \\
\text { and Climate change }\end{array}$ & $\begin{array}{l}\text { Scientific institution; } \\
\text { member of Swiss } \\
\text { Academy of } \\
\text { Natural Sciences }\end{array}$ & $\begin{array}{l}\text { Intermediate } \\
\text { group }\end{array}$ & Pro-ecology \\
\hline $\mathrm{OcCC}$ & $\begin{array}{l}\text { Advisory Body } \\
\text { on Climate } \\
\text { Change }\end{array}$ & $\begin{array}{l}\text { Scientific institution } \\
\text { formulating } \\
\text { recommendation } \\
\text { to the Swiss } \\
\text { Parliament; } \\
\text { member of the } \\
\text { Swiss Academy of } \\
\text { Natural Sciences }\end{array}$ & $\begin{array}{l}\text { Intermediate } \\
\text { group }\end{array}$ & Pro-ecology \\
\hline AEE & $\begin{array}{l}\text { Agency for } \\
\text { renewable } \\
\text { Energy }\end{array}$ & $\begin{array}{l}\text { Advisory organization } \\
\text { for renewable } \\
\text { energy issues }\end{array}$ & $\begin{array}{l}\text { Intermediate } \\
\text { group }\end{array}$ & Pro-ecology \\
\hline Greenpeace & & Green NGO & $\begin{array}{l}\text { Intermediate } \\
\text { group }\end{array}$ & Pro-ecology \\
\hline WWF & $\begin{array}{l}\text { World Wildlife } \\
\text { Foundation }\end{array}$ & Green NGO & $\begin{array}{l}\text { Intermediate } \\
\text { group }\end{array}$ & Pro-ecology \\
\hline FOEN & $\begin{array}{l}\text { Federal Office } \\
\text { for the } \\
\text { Environment }\end{array}$ & Federal agency & Pro-ecology & Pro-ecology \\
\hline ATE & $\begin{array}{l}\text { Association } \\
\text { Transport and } \\
\text { Environment }\end{array}$ & $\begin{array}{l}\text { Organization } \\
\text { promoting public } \\
\text { transport and } \\
\text { environmental } \\
\text { solutions in } \\
\text { private } \\
\text { transportation }\end{array}$ & Pro-ecology & Pro-ecology \\
\hline PSS & $\begin{array}{l}\text { Social Democratic } \\
\text { Party of } \\
\text { Switzerland }\end{array}$ & $\begin{array}{l}\text { Two seats in the } \\
\text { Federal Council } \\
\text { (government); } \\
19.5 \% \text { of the votes } \\
\text { and } 43 \text { seats in the } \\
\text { National Council } \\
\text { (lower chamber) }\end{array}$ & Pro-ecology & Pro-ecology \\
\hline GPS & $\begin{array}{c}\text { Green Party of } \\
\text { Switzerland }\end{array}$ & $\begin{array}{l}0 \text { seats in the Federal } \\
\text { Council } \\
\text { (government); } \\
9.6 \% \text { of the votes } \\
\text { and } 20 \text { seats in the } \\
\text { National Council } \\
\text { (lower chamber) }\end{array}$ & Pro-ecology & Pro-ecology \\
\hline TravailSuisse & & $\begin{array}{l}\text { Association of } \\
\text { Trade Unions }\end{array}$ & Pro-ecology & $\begin{array}{l}\text { Intermediate } \\
\text { group }\end{array}$ \\
\hline
\end{tabular}




\section{REFERENCES}

Arce, Daniel. 2001. Leadership and the aggregation of international collective action. Oxford Economic Papers 53:114-37.

Baumgartner, Frank R., and Bryan D. Jones. 1993. Agendas and instability in American politics. Chicago, IL: Univ. of Chicago Press.

Beach, Derek. 2004. The unseen hand in treaty reform negotiations: The role and influence of the Council Secretariat. Journal of European Public Policy 11:408-39.

Charles Brecher, Caitlyn Brazill, Beth C. Weitzman, and Diana Silver. 2010. Understanding the Political Context of New Policy Issues: the Use of the Advocacy Coalition Model in the Case of Expanded After-School Programs. Journal of Public Administration, Research and Theory 20(2):235-255.

Christopoulos, Dimitris. 2008. Political entrepreneurs: Network structure and power. www.psa.ac.uk/ journals/pdf/5/2008/Christopoulos.pdf (accessed July 11, 2011).

Elliott, Christopher. 2000. Forest certification. A policy perspective Thesis Series. Bogor, Indonesia: CIFOR.

Federal Council. 1997. Message relatif à la loi fédérale sur la réduction des émissions de $\mathrm{CO}_{2}$. Berne, Switzerland: Archives fédérales suisses.

Fischer, Alex. 2003. Die Auswirkungen der Internationalisierung/Europäisierung auf den Schweizer Entscheidungsprozess. Lausanne, Switzerland: IDEHAP.

Freeman, Linton C. 1979. Centrality in social networks: I. Conceptual clarification. Social Networks 1:215-39.

Gerlak, Andrea, and Tanya Heikkila. 2011. Building a theory of learning in collaboratives: Evidence from the everglades restoration program. Journal of Public Administration Research and Theory doi: 10.1093/jopart/muq089 First published online: February 9, 2011.

Goldfinch, Shaun, and Paul Hart. 2003. Leadership and institutional reform: Engineering macroeconomic policy change in Australia. Governance 16:235-70.

Holcombe, Randall. 2002. Political entrepreneurship and the democratic allocation of economic resources. The Review of Austrian Economics 15:143-59.

Ingold, Karin. 2008. Les mécanismes de décision: Le cas de la politique climatique Suisse. Zürich, Switzerland: Politikanalyen, Rüegger.

2010. Apprendre pour le futur: Une analyse de la politique climatique suisse. Swiss Political Science Review 16:43-76.

Ingold, Karin. 2011. Network structures within policy processes: Coalitions, power and brokerage in Swiss climate policy. Policy Studies Journal 39(3):435-59.

James, Thomas E., and Paul D. Jorgersen. 2009. Policy knowledge, policy formulation, and change. Revisting a foundational question. The Policy Studies Journal 37:141-62.

Jegen, Maja. 2003. Energiepolitische Vernetzung in der Schweiz Thèse no. 516, Univ. de Genève

Jenkins-Smith, Hank, and Gilbert St. Clair. 1993. The politics of offshore energy: Empirically testing the advocacy coalition framework. In Policy change and learning, eds. Paul A. Sabatier and Hank Jenkins-Smith, 149-76. Boulder, CO: Westview.

Jobert, Bruno, and Pierre Muller. 1987. L'Etat en action. Politiques publiques et corporatismes. Paris: Presses Universitaires de France.

Kingdon, John. 1995. Agenda, alternatives and public policies, 2nd ed. New York: Harper Collins.

Knoke, David, Franz U. Pappi, Jeffry Broadbent, and Yutaka Tsujinaka. 1996. Comparing policy networks-labour politics in the US, Germany and Japan. Cambridge: Cambridge Univ. Press.

Kiser, Larry, and Elinor Ostrom. The three worlds of action: A meta-theoretical synthesis of institutional approaches. In Strategies of political inquiry ed. Elinor Ostrom, 179-222. Beverly Hills, CA: Sage..

Kriesi, Hanspeter, and Maya Jegen. 2000. Decision-making in the Swiss energy policy elite. Journal of Public Policy 20:21-53.

2001. The Swiss energy policy elite: The actor constellation of a policy domain in transition. European Journal of Political Research 39:251-87.

Kübler, Daniel. 2001. Understanding policy change with the advocacy coalition framework: An application to Swiss drug policy. Journal of European Public Policy 8:623-41. 
Kuhnert, Stephan. 2001. An evolutionary theory of collective action: Schumpeterian entrepreneurship for the common good. Constitutional Political Economy 12:13-29.

Lehmann, Luzia, and Stefan Rieder. Wissenschaftliches Wissen in Politischer Auseinandersetzung, Bericht 34. Bern: SATW.

Lijphart, Arend. 1999. Patterns of democracy. Government forms and performance in thirty-six countries. New Haven, CT: Yale Univ. Press.

Lüthi, Ruth. 2007. The parliament. In: Handbooks of Swiss politics, eds. Ulrich Klöti, Peter Knoepfel, Hanspeter Kriesi, Wolf Linder, Yannis Papadopoulos, and Pascal Sciarini, 121-44. NZZ.

Meijerink, Sander. 2005. Understanding policy stability and change. The interplay of advocacy coalitions and epistemic communities, windows of opportunity, and Dutch coastal flooding policy 1945-2003. Journal of European Public Policy 12:1060-77.

Mintrom, Michael, and Phillipa Norman. 2009. Policy entrepreneurship and policy change. Policy Studies Journal 37:649-67.

Mintrom, Michael, and Sandra Vergari. 1996. Advocacy coalitions, policy entrepreneurs, and policy change. Policy Studies Journal 24:420-34.

Nagel, Peter. 2006. Policy games and venue-shopping: Working the stakeholder interface to broker policy change in rehabilitation services. Australian Journal of Public Administration 65:3-16.

Neidhart, Leonhard. 1970. Plebiszit und pluralitäre Demokratie. Eine Analyze der Funktion des schweizerischen Gesetzesreferendums. Bern, Switzerland: Francke.

Nohrstedt, Daniel. 2009a. External shocks and policy change: Three Mile Island and Swedish nuclear energy policy. Journal of European Public Policy 12:1041-59.

-2009b. Do advocacy coalitions matter? Crisis and change in Swedish nuclear energy policy. Journal of Public Administration Research and Theory 11.

Nohrstedt, Daniel, and Christopher M. Weible. 2010. The logic of policy change after crisis: Proximity and subsystem interaction. Risk, Hazards \& Crisis in Public Policy 1 (2): 1-32.

Ostrom, Elinor. 2005. Understanding institutional diversity. Princeton, NJ: Princeton Univ. Press.

- 2007. Institutional rational choice: An assessment of the institutional analysis and development framework. In: Theories of the policy process, 2nd ed., ed. Paul A. Sabatier. Boulder, CO: Westview.

Papadopoulos, Yannis. 2001. How does direct democracy matter? The impact of referendum votes upon politics and policy-making. West European Politics 24:35-58.

Sabatier, Paul A. 1988. An advocacy coalition framework of policy change and the role of policy-oriented learning therein. Policy Sciences 21:129-68.

1993. Advocacy-Koalitionen, Policy-Wandel und Policy-Lernen: Eine Alternative zur Phasenheuristik. Politische Vierteljahresschrift, Sonderaus 24:116-48.

Sabatier, Paul A., and Christopher M. Weible. 2007. The advocacy coalition framework. Innovations and clarifications. In Theories of the policy process, 2nd ed., ed. Paul A. Sabatier. Boulder, CO: Westview.

Sabatier, Paul A., and Hank Jenkins-Smith. 1993. Policy change and learning. An advocacy coalition approach. Boulder, CO: Westview.

Sabatier, Paul, Susan Hunter, and Susan McLaughlin. 1987. The devil shift: Perceptions and misperceptions of opponents. Political Research Quarterly 40:449-76.

Schärlig, Andreas. 1985. Décider sur plusieurs critères-Panorama de l'aide à la décision multicritère. Lausanne, Switzerland: Presses polytechniques et universitaires romandes.

Schneider, Mark, and Paul Teske. 1992. Towards a theory of the political entrepreneur: Evidence from local government. American Political Science Review 86:734 47.

Schlager, Edella. 1995. Policy making and collective action: Defining coalitions within the advocacy coalition framework. Policy Sciences 28:243-70.

Schumpeter, Joseph. 1961. A theory of economic development. Oxford: Oxford Univ. Press.

Sciarini, Pascal. 1994. Le système politique suisse face à la Communauté européenne et au GATT: Le castest de la politique agricole $\mathrm{PhD}$ diss. no. 394, Université de Genève.

Stokman, Frans. 2004. What binds us when with whom? Extended key notes at the Sunbelt XXIV, Slovenia.

Tallberg, Jonas. 2004. The power of the presidency: Brokerage, efficiency and distribution in EU negotiations. Journal of Common Market Studies 42:990-1022. 
Thalmann, Philippe, and Andrea Baranzini. 2006. Gradual introduction of coercive instruments in climate policy. Cahier de recherche 06/6/1. Geneva, Switzerland: Haute école de gestion de Genève.

Tsebelis, George. 1995. Decision making in political system. Veto players in presidentialism, parliamentarism, mutlicameralism, and mutlipartyism. British Journal of Political Science 25:289-325.

- 2002. Veto players: How political institutions work. Princeton, NJ: Princeton Univ. Press.

Varone, Frédéric, and Bernard Aebischer. 2001. Energy efficiency: The challenges of policy design. Energy Policy 29:615-9.

Varone, Frédéric, Christine Rothmayr, and Eric Montpetit. 2006. Regulating biomedicine in Europe and North America. A qualitative-comparative analysis. European Journal of Political Research 45:317-43.

Vatter, Adrian. 2009. Lijphart expanded: Three dimensions of democracy in advanced OECD countries? European Political Science Review 1:125-54.

Walgrave, Stefaan, and Frédéric Varone. 2008. Punctuated equilibrium and agenda-setting: Bringing parties back in policy change after the Dutroux crisis in Belgium. Governance 23:365-95.

Wasserman, Stanley, and Katherine Faust. 1994. Social network analysis: Method and applications. Cambridge: Cambridge Univ. Press.

Weible, Christopher. 2007. An advocacy coalition framework approach to stakeholder analysis: Understanding the political context of California Marine Protected Area Policy. Journal of Public Administration Research and Theory 17:95-117.

Weible, Christopher M., Paul A. Sabatier, and Kelly McQueen. 2009. Themes and variations: Taking stock of the advocacy coalition framework. Policy Studies Journal 37:121-40.

Zachariadis, Nikolaos. 2007. The multiple streams framework: Structure, limitations, prospects. In: Theories of the policy process, 2nd ed, ed. Paul A. Sabatier. Boulder, CO: Westview. 